\title{
薬物性白血球減少症の危険因子及び自覚症状に関する研究
}

\author{
林 恭子, ${ }^{*}, a$ 大津史子, ${ }^{a}$ 矢野玲子, ${ }^{b}$ 棉原仁作, ${ }^{a}$ 後藤伸之 ${ }^{a}$
}

\section{Risk Factors and Subjective Symptoms of Drug-induced Leucopenia}

\author{
Kyoko Hayashi, ${ }^{*, a}$ Fumiko OHTSU, ${ }^{a}$ Reiko YANO, ${ }^{b}$ \\ Jinsaku SAKAKIBARA, ${ }^{a}$ and Nobuyuki Goto ${ }^{a}$ \\ ${ }^{a}$ Drug Informatics, Faculty of Pharmacy, Meijo University, 150 Yagotoyama, Tempaku-ku, \\ Nagoya 468-0077, Japan, and ${ }^{b}$ College of Pharmacy, Kinjo Gakuin University, \\ 2-1723 Ohmori, Moriyama-ku, Nagoya 463-0021, Japan
}

(Received May 27, 2010; Accepted October 5, 2010; Published online October 22, 2010)

\begin{abstract}
The present study investigated risk factors and subjective symptoms associated with drug-induced leucopenia. We selected 248 patients with drug-induced leucopenia from the Case Reports of Adverse Drug Reactions and Poisoning Information System (CARPIS) database of over 47000 case reports of adverse drug reactions and assigned them to a case group. We also randomly selected 743 cases of adverse drug reactions not associated with leucopenia as a control group. A comparison of patient characteristic data between the two groups using logistic-regression analysis revealed that female sex, autoimmune disease and renal damage were background risk factors for drug-induced leucopenia. In addition, thiamazole, ritodrine, propylthiouracil, ticlopidine, allopurinol, minocycline and captopril administration significantly increased the risk of drug-induced leucopenia. A significant association was also found for fever, chills and pharyngeal abnormalities. Based on these findings, we developed two estimated regression equations to help prevent drug-induced leucopenia in the community pharmacy setting.
\end{abstract}

Key words — drug-induced leucopenia; case-control study; patient background; subjective symptom; adverse drug reaction

緒言

薬物性白血球減少症は生命を脅かす重篤な副作用 であり，特に白血球が $500 / \mathrm{mm}^{3}$ 未満の状態を無顆 粒球症と呼ぶ. 1988 年から行われた国際的な薬物 性無顆粒球症の疫学研究 IAAAS（International Agranulocytosis and Aplastic Anemia Study) では, その発現は 1 年間で 100 万人あたり 3.4 人と稀であ つたことが報告されている. ${ }^{1)} し か し ，$ 白血球減少 症は免疫能の低下を引き起こし, 肺炎や敗血症とい

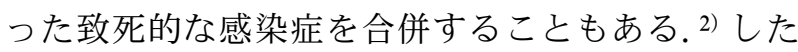
がって，これらを念頭に置き，医薬品を使用するこ とが必要である.

副作用が発現した場合には，薬物治療の中止や変 更で治療期間が延長し，治療費が増大するばかりで なく，患者の肉体的，精神的な負担は非常に大き

$a$ 名城大学薬学部医薬品情報学研究室, ${ }^{b}$ 金城学院大学 薬学部

*e-mail: h.kyoko0324@hotmail.co.jp
い. 医薬品を使用する際に副作用を完全に避けるこ とはできないが，できるだけ早期に発見し重篤化を 防ぐことができればこれらの負担を減らすことがで きる。しかし，副作用の発現には個人差があり，症 状や程度も様々であるため，その症状が副作用かど うかの判断は難しい.

厚生労働省では重篤副作用疾患総合対策事業とし て，医薬品の安全性に関する副作用対策を事後対応 型に加え予測・予防型の対応整備を進めている. ${ }^{3)}$ 2007 年からは重篤な副作用に対応するために重篤 副作用疾患別対応マニュアル（以下，厚労省マニュ アルとする）を作成しており，その第 1 集には無顆 粒球症の原因薬や危険因子などが記載されてい る.4)しかし，日本においては薬物性白血球減少症 の危険因子に関する疫学研究は行われておらず，白 血球減少症のような稀な副作用の危険因子を明らか にするためにはケースコントロール研究が最も合理 的な手法であると考えられる。

そこで今回，薬物性白血球減少症の危険因子と自 
覚症状を明らかにすることを目的として，国内の症 例報告を用いて, 薬物性白血球減少症を起こした症 例報告を対象としたケースコントロール研究を行っ た。さらに，得られた回帰式を用いて実際に早期発 見する方法論を検討した.

\section{方法}

1. 材料 CARPIS (Case Reports of Adverse Drug Reaction Information System) は名城大学薬 学部医薬情報センターで作成している副作用，中毒 症例報告データベースシステムである．国内で報告 された症例を収集し，電子化することで，原因薬や 患者背景等を検索し，参照できるだけでなく，その 内容を集計できるファクトデータベースである. ${ }^{5)}$ 2008 年 11 月現在， 1987 年から 2008 年の約 22 年間 に国内で報告された約 47563 文献（有効症例 44563 症例）を収録している。なお，有効症例とは症例報 告が入力者により CARPIS に入力され，かつ他者 によるチェックを受けて正式に登録された症例のこ とを指す。今回は CARPIS に収録されている白血 球減少症についての症例を材料としてケースコント ロール研究を行った.

2. データベースの妥当性評価副作用の症例 報告は，自発的な報告であるため，話題となった副 作用や珍しい副作用，重篤な副作用が多く報告さ れ，偏りを生ずる可能性がある。そこで，CARPIS の副作用症例報告収録の網羅性と副作用の偏りを検 証することで CARPIS を副作用コホートとして利 用することの妥当性を評価した．CARPIS は，4つ の既存の医学系文献データベース（JMEDPlus，医 中誌 DB, iyakuSearch，国内医薬文献）からの情報 とハンドサーチによって症例報告を収集してい る. ${ }^{6)}$ そこで, これらのデータベースの副作用の症 例報告数をカウントし，CARPIS と比較すること で網羅性の指標とした。データベースの偏りは, CARPIS に収録されているすべての副作用症例報 告が主題としている副作用の臟器別分類を調査し, その分布 (以下, 副作用藏器別分類分布と略す) と, 各年度別の副作用臓器別分類分布との間に差がある かを $\chi^{2}$ の独立性の検定を行い確認した。

JMEDPlus は, 独立行政法人科学技術振興機構 が作成した文献情報検索システム JDream II の医 学系データベースである。1981 年以降に日本国内
で発表された医学・薬学・歯科学・看護学・生物科 学・獣医学等の文献情報約 500 万件の論文情報が収 録されている. ${ }^{7)}$ 医中誌 DB は, 特定非営利活動法 人医学中央雑誌刊行会が作成する国内医学論文デー タベースである. 国内発行の医学, 歯学, 薬学及び 看護学などの関連分野の定期刊行物約 5000 誌から 収録した約 660 万件の論文情報を検索することがで きる. ${ }^{8)}$ iyakuSearch は財団法人日本医薬情報セン 夕ーが提供する国内外の医薬品情報に関するデー夕 ベースである，医薬文献情報，学会演題情報，医薬 品添付文書情報, 臨床試験情報, 日本の新薬，学会 開催情報, 効能効果の対応標準病名を検索すること ができる. ${ }^{9)}$

3. 対象症例の抽出 今回対象としたケース 群，コントロール群の抽出方法を Fig. 1 に示した.

3-1. ケース群の抽出ＣARPIS に収録されて いる有効症例のうち，白血球減少症が中心に記述さ れている症例は 698 症例であった。この中から副作 用の原因が医薬品以外 (食品, 工業用品，農薬なぞ) の症例と皮膚投与の症例を除外した。ささらに，二次 性白血球減少症として銅欠乏性貧血，銅欠乏症によ る白血球減少症を除外した。また，抗がん薬は用量 依存的に造血幹細胞や造血前駆細胞の分化と増殖を 障害し，血球減少を引き起こす。4)したがって抗が ん薬による白血球減少症は予測される副作用であ り，症例報告の対象とならないことが多いので今回 の対象からは除外した。次に量的及び質的に一定水 準以上の良質な症例を材料とするため，大津ら ${ }^{10)} の$ 考案した副作用症例報告評価方法（副作用症例報告 基準記載事項の評価基準・副作用因果関係の評価基 準）を用いて症例評価を行った。さらに，確実に薬 物性の白血球減少症である症例を対象とするために CIOMS (Council for International Organization of Medical Sciences) ${ }^{11)}$ の基準を参考に抽出基準を以下 のように設定した.

- 症状の発現に時間的因果関係（薬物使用後に 発症）がある。

- 原因推定薬物の減量・中止後に軽快若しくは 死亡した.

- 検査で白血球系異常（白血球減少，顆粒球減 少，好中球減少のいずれか) がある.

この条件をすべて満たす症例を抽出し, 同一症例 を除いたところケース群は 248 症例となった。 


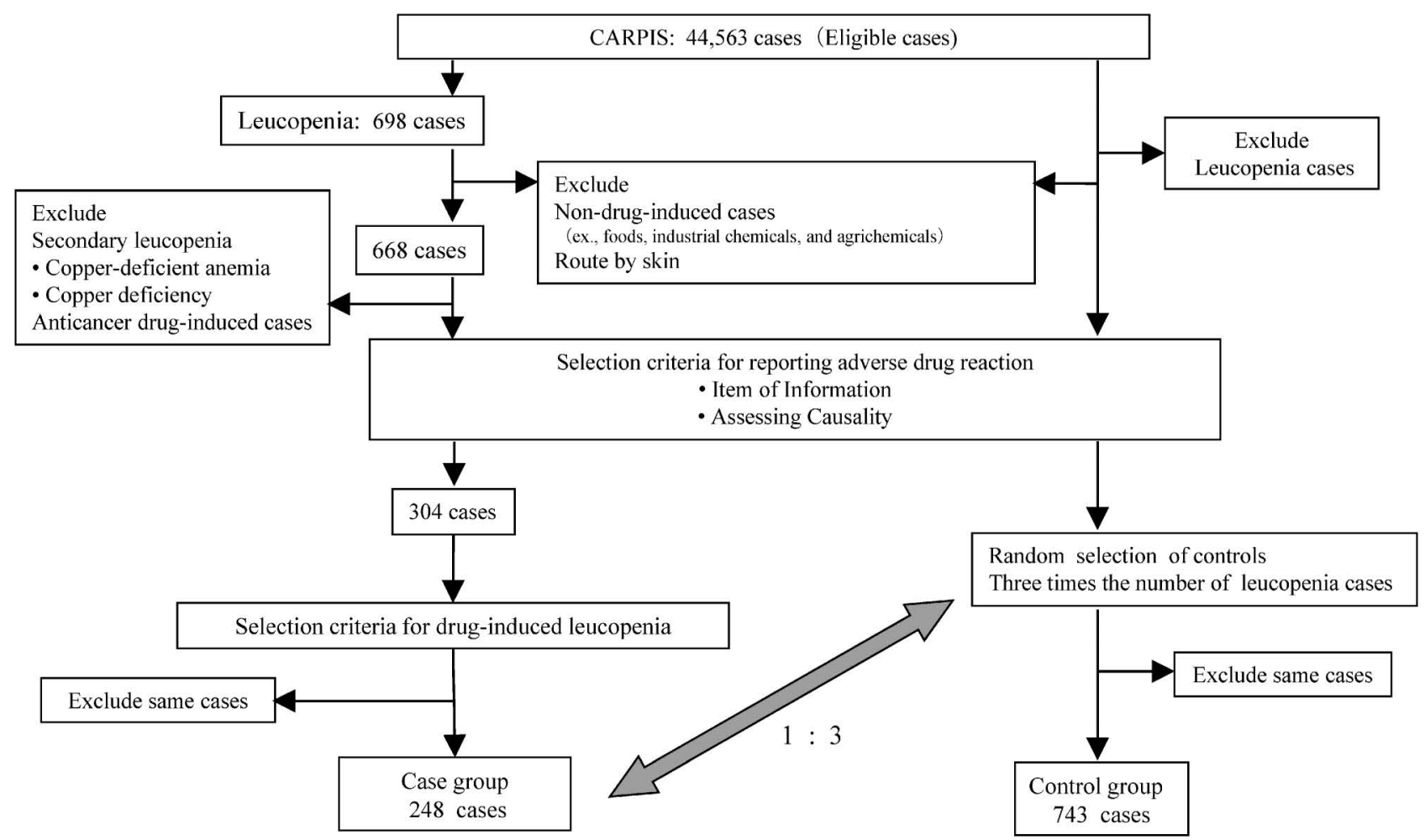

Fig. 1. Extraction Methods for Leucopenia Cases and Control Cases

3-2. コントロール群の抽出ＣARPIS に収録 されている有効症例から，薬物による白血球減少症 が中心に記述されている症例を除外した，次に副作 用の原因が医薬品以外 (食品, 工業用品, 農薬など) の症例と皮膚投与の症例を除外した。ささらに，副作 用症例報告記載事項の評価基準・副作用因果関係の 評価基準を用いて症例評価を行った，基準に適合し た症例から，ケース群の 1 症例に対してコントロー ル群を ID-No. に基づいてランダムに 3 症例抽出し た。最後に同一症例を除外したところ，コントロー ル群は 743 症例となった。今回抽出したコントロー ル群が副作用の母集団を反映しているかどうかを確 認するために，コントロール群の副作用臟器別分類 分布と CARPIS 収録全症例の副作用臓器別分類分 布について $\chi^{2}$ 独立性の検定を行い，コントロール として使用できるか判断した。

4. 調査項目 ケース群 248 症例とコントロー ル群 743 症例の報告内容から，以下の項目について 調査した。患者背景としては，性別，年齢，年代 (0-19 歳, 20-39 歳, 40-59 歳, 60-79 歳), 高齢 （65 歳以上），また，原疾患・対象疾患，既往歴， 原因薬の一般名及び薬効分類名，さらに，自覚症
状，初期症状について調査した。なお，自覚症状は 主訴として記載のあるもの，その中で時間的経過か ら初期に発現したと明確に確認できる症状を初期症 状とした。原因薬については，一般名でケース群に 4 症例以上あったもの，薬効分類名でケース群に 10 症例以上あったものをそれぞれ解析対象とした。た だし，同一症例で同じ薬効の薬物を 2 剤以上使って いることがあるため, 精神神経用薬の症例数は 8 症 例となつた。自覚症状，初期症状については，自覚 症状がケース群で 10 症例以上の発現がみられたも のを解析対象とした.

5. 統計方法 白血球減少症に特異的な因子を 検索するため, ケース群及びコントロール群の 2 群 間で，調査項目毎に単変量ロジスティック回帰分析 を行った.

次に単変量ロジスティック回帰分析において $p$ 值 $<0.2$ を認めた項目を選択し，項目間での交絡を 調節するために多変量ロジスティック回帰分析を行 い，オッズ比， $p$ 值及び $95 \%$ 信頼区間（95\% Confidence Interval: 95\% C.I.) をそれぞれ算出した。症 状に関してはオッズ比が 1 以上となった項目を対象 とした，多変量ロジスティック回帰分析は，患者背 
景と原因薬 (一般名)，患者背景と原因薬（薬効分 類名）を行った。症状については，副作用発現後に 起こるものであり，患者背景や原因薬とは同時に解 析できないため，自覚症状，初期症状それぞれで解 析を行った。有意水準は 0.05 , 統計ソフトは

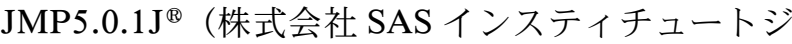
ヤパン）を用いた。

\section{6.リスク因子確率と自覚症状確率の算出とカッ} トオフ值多変量ロジスティック回帰分析におい て有意な関連が認められた患者背景と原因薬（一般 名）（以下，2つを合わせてリスク因子という)，自 覚症状の項目を用いて白血球減少症を推定するため の回帰式（リスク因子式，自覚症状式）をそれぞれ 作成した。 得られた回帰式を用いて，ケース群及び コントロール群の各症例の薬物性白血球減少症の確 率（リスク因子確率，自覚症状確率）を算出した。

リスク因子確率及び自覚症状確率によって，ケース 群及びコントロール群が正しく推測できるかを検討 した，得られた各症例のリスク因子確率，自覚症状 確率の発現頻度から尤度比を算出した。ささらに，作 成した回帰式についての ROC 曲線を作成した，尤 度比が 1 以上で，かつ， ROC 曲線において感度 $100 \%$, 特異度 $100 \%$ から最も近い距離の值をカッ トオフ值とした. 確率がカットオフ值以上を陽性, カットオフ值未満を陰性として推定した。

\section{7. 回帰式の妥当性評価回帰式の妥当性評価} について，推定結果を基に，感度，特異度，尤度比 を求めた。さらに, より臨床に則した評価を行うた めに, 白血球減少症の有病率を文献報告数から求め (推定有病率)，推定有病率における推定陽性反応的 中度をリスク因子確率，自覚症状確率でそれぞれ算 出し，回帰式の妥当性評価をした。また，リスク因 子確率及び自覚症状確率を二次元に表現し，薬剤師 の対応行動を示した。

推定有病率の求め方は以下の通りとした.

推定有病率 $=$ CARPIS 白血球減少症症例数/

(CARPIS 全症例数/副作用有病率)

結果

\section{1. データベースの妥当性評価とコントロール群} の妥当性 既存の医学系文献データベースに 1987 年 1 月から 2008 年 11 月の間に収録された副 作用症例報告件数は，JMedPlus が 34232 件，医中
誌 DB が 29560 件，iyakuSearch が 9900 件であつ た。国内医薬文献は，1991 年 6 月から 2008 年 11 月のデータであるが 47147 件であった．ただし，国 内医薬文献は，複数製剤が原因となる場合，その数 分カウントしているため，正確な文献数は不明であ る。以上より，CARPIS の収録文献数 47563 文献 （有効症例 44563 症例）と比較すると, CARPIS の 副作用症例報告収録規模がいずれのデータベースを も上回っており，国内の副作用症例報告を網羅的に 収集できていると判断できた。また，CARPIS 収 録文献全体の副作用の臟器別分類分布と，各年度別 の副作用臓器別分類分布との間に差があるかを $\chi^{2}$ の独立性の検定を行い確認した，その結果，いずれ も $p$ 值が 0.236-0.26であり，有意な差はなく, CARPIS 収録全文献と各年度で副作用の流行によ る偏りはないと判断した。したがって，CARPIS は副作用の流行を十分に吸収し，副作用症例報告の コホートとみなすことができた。

また，今回抽出したコントロール群は, CARPIS 全副作用症例報告の副作用臟器別分類分布との間に 有意な差はなく（ $p=0.377 ）$ ，コントロール群は副 作用の母集団を反映しているとみなし，コントロー ルとして使用できるものであった.

2. 単変量ロジスティック回帰分析単変量口 ジスティック回帰分析結果を Table 1 に示す.

患者背景の項目で有意なリスク増加がみられたも のは，性別の「女性」，原疾患・対象疾患の「自己 免疫疾患」,「腎障害」, 既往歴の「腎障害（既往）」 であった．有意なリスク低下がみられたものは，年 齢の項目で年代の「60-79歳」「高齢」であった。 原因薬（一般名）の項目で有意なリスク増加がみら れたものは「チアマゾール」,「塩酸リトドリン」, 「プロピルチオウラシル」，「メトトレキサート」, 「塩酸チクロピジン」, 「アロプリノール」, 薬効分類 名の項目では「甲状腺・副甲状腺ホルモン」,「消化 性潰瘍薬」,「抗リウマチ薬」,「その他の泌尿生殖器 官・肛門用薬」，「サルファ剂」であった．有意なリ スク低下がみられたものは薬効分類名の「精神神経 用薬」であった。自覚症状の項目で薬物性白血球減 少症と有意な正の関連がみられたものは，「発熱・ 悪寒」, 「貧血」, 「咽頭異常」,「口内・舌の異常」, 「出血傾向」, 初期症状の項目では, 「発熱・悪寒」, 「咽頭異常」,「出血傾向」,「貧血」であった，自覚 
Table 1. Logistic Regression Analysis

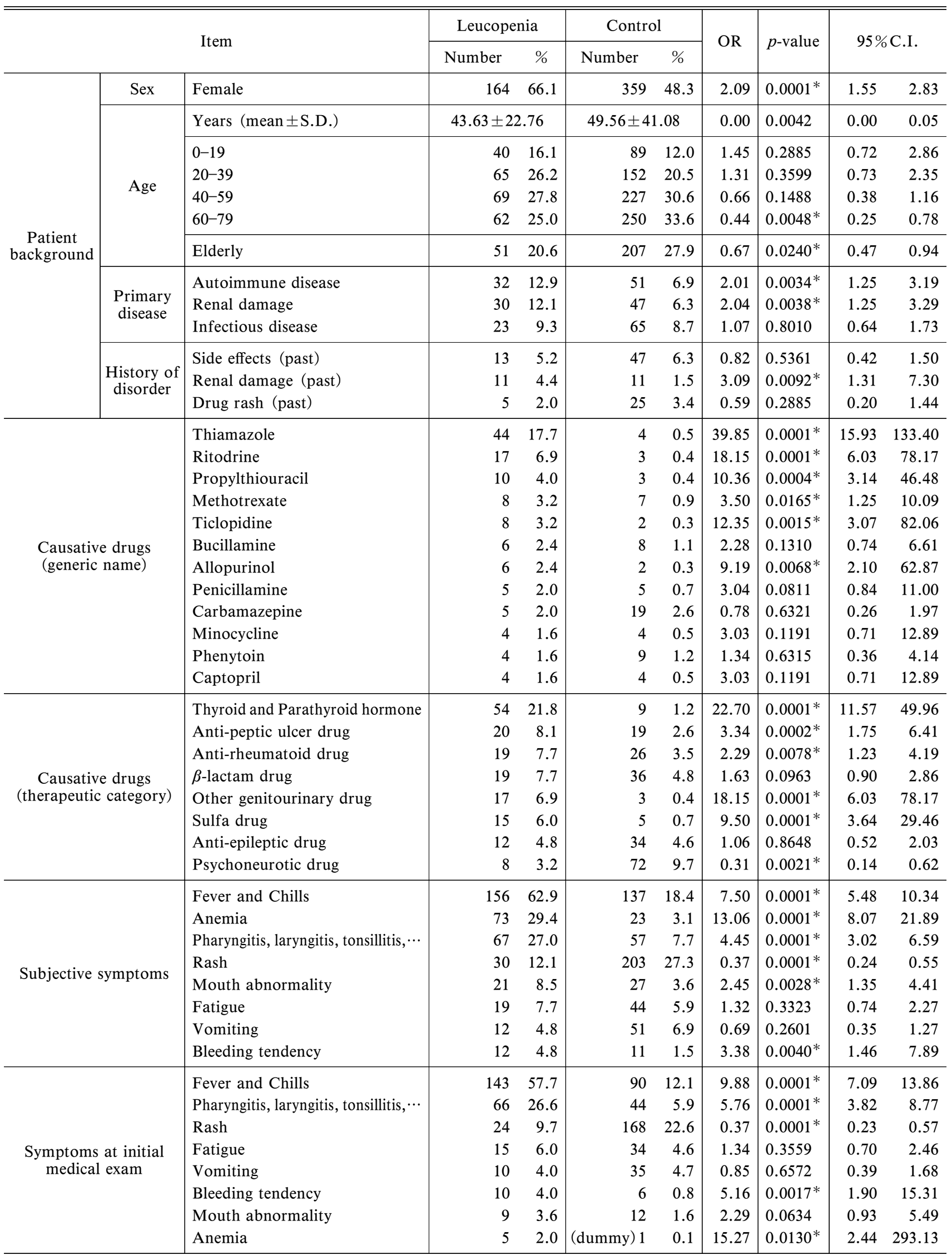

\footnotetext{
${ }^{*} p$-value $<0.05$. OR: odds raito
} 
症状の項目で有意な負の関連がみられた項目は「薬 疹」であった。初期症状の項目でも「薬疹」であつ た. 初期症状における「貧血」はコントロール群が もともと 0 例で解析不能であったため, ダミーとし て 1 例を加えて解析を行った.

3. 患者背景と原因薬（一般名）の多変量ロジス ティック回帰分析 患者背景と原因薬（一般名） の多変量ロジスティック回帰分析結果を Table 2 に 示す。有意なリスク増加がみられたものは, 患者背 景の項目で，「女性」（オッズ比 1.43, 95\% C.I. 1.00 -2.06 ), 「自己免疫疾患」（オッズ比 $2.23,95 \%$ C.I. 1.19-4.02），「腎障害」（オッズ比 1.95 , 95 \% C.I. 0.99-3.70), 原因薬（一般名）の項目で, 「チアマ ゾール」（オッズ比 54.68, 95\% C.I. 21.45-185.14),

「塩酸リトドリン」（オッズ比 $26.88,95 \%$ C.I. 8.69117.71),「プロピルチオウラシル」（オッズ比 15.97, 95\% C.I. 4.73-72.69), 「塩酸チクロピジン」 （オッズ比 21.62, 95\% C.I. 5.12-146.63），「アロプ リノール」（オッズ比 7.05, 95\% C.I. 1.43-51.86）,

「塩酸ミノサイクリン」（オッズ比 5.27, 95 \% C.I. 1.22-22.73), 「カプトプリル」（オッズ比 $4.87,95 \%$ C.I. 1.08-21.77) であった.

4. 患者背景と原因薬（薬効分類名）における多 変量ロジスティック回帰分析患者背景と原因薬
（薬効分類名）における多変量ロジスティック回帰 分析結果を Table 3 に示す。有意なリスク増加がみ られたものは，患者背景の項目で，「腎障害」(オッ ズ比 2.71, 95\% C.I. 1.42-5.03), 原因薬（薬効分類 名）の項目で，「甲状腺・副甲状腺ホルモン」（オッ ズ比 33.84, 95\% C.I. 16.64-76.56), 「消化性潰瘍薬」 （オッズ比 5.81, 95\% C.I. 2.91-11.63），「抗リウマ チ薬」（オッズ比 3.94, 95\%C.I. 1.47-10.97），「 $\beta$ ラ クタム系」（オッズ比 3.24, 95 \% C.I. 1.73-5.91）, 「その他の泌尿生殖器官・肛門用薬」（オッズ比 29.92, 95\% C.I. 9.60-131.59)，「サルファ剂」（オッ ズ比 19.14, 95\% C.I. 6.89-62.31） であった.

5. 自覚症状及び初期症状の多変量ロジスティッ ク回帰分析 自覚症状及び初期症状の多変量ロジ スティック回帰分析結果を Table 4 にそれぞれ示 す。自覚症状で有意な正の関連がタられたものは, 「発熱・悪寒」（オッズ比 $6.85,95 \%$ C.I. 4.78 9.91 ), 「貧血」（オッズ比 $14.19,95 \%$ C.I. 8.23 25.22), 「咽頭異常」（オッズ比 $2.06,95 \%$ C.I. 1.28 -3.32) であった.

初期症状で有意な正の関連がみられたものは, 「発熱・悪寒」（オッズ比 $8.08,95 \%$ C.I. $5.67-$ 11.57), 「咽頭異常」（オッズ比 $2.45,95 \%$ C.I. 1.51 -3.99), 「出血傾向」（オッズ比 3.94, 95\% C.I. 1.15

Table 2. Multivariate Logistic Regression Analysis (Patient Background Factor vs. Drug)

\begin{tabular}{|c|c|c|c|c|c|c|c|c|c|}
\hline & \multirow{2}{*}{ Item } & \multicolumn{2}{|c|}{ Leucopenia } & \multicolumn{2}{|c|}{ Control } & OR & $p$-value & \multicolumn{2}{|c|}{$95 \%$ C.I. } \\
\hline & & & & & & & & & \\
\hline \multirow{6}{*}{ Patient background } & Female & 164 & 66.1 & 359 & 48.3 & 1.43 & $0.0480^{*}$ & 1.00 & 2.06 \\
\hline & Elderly & 51 & 20.6 & 207 & 27.9 & 0.89 & 0.5448 & 0.59 & 1.31 \\
\hline & Autoimmune disease & 32 & 12.9 & 51 & 6.9 & 2.23 & $0.0094^{*}$ & 1.19 & 4.02 \\
\hline & Renal damage & 30 & 12.1 & 47 & 6.3 & 1.95 & $0.0461^{*}$ & 0.99 & 3.70 \\
\hline & Renal damage (past) & 11 & 4.4 & 11 & 1.5 & 2.47 & 0.0990 & 0.84 & 7.30 \\
\hline & Drug rash (past) & 5 & 2.0 & 25 & 3.4 & 0.62 & 0.3914 & 0.19 & 1.68 \\
\hline \multirow{10}{*}{$\begin{array}{l}\text { Causative drugs } \\
\text { (generic name) }\end{array}$} & Thiamazole & 44 & 17.7 & 4 & 0.5 & 54.68 & $0.0001 *$ & 21.45 & 185.14 \\
\hline & Ritodrine & 17 & 6.9 & 3 & 0.4 & 26.88 & $0.0001^{*}$ & 8.69 & 117.71 \\
\hline & Propylthiouracil & 10 & 4.0 & 3 & 0.4 & 15.97 & $0.0001^{*}$ & 4.73 & 72.69 \\
\hline & Methotrexate & 8 & 3.2 & 7 & 0.9 & 2.73 & 0.0825 & 0.87 & 8.67 \\
\hline & Ticlopidine & 8 & 3.2 & 2 & 0.3 & 21.62 & $0.0002^{*}$ & 5.12 & 146.63 \\
\hline & Bucillamine & 6 & 2.4 & 8 & 1.1 & 1.67 & 0.4161 & 0.47 & 5.75 \\
\hline & Allopurinol & 6 & 2.4 & 2 & 0.3 & 7.05 & $0.0254^{*}$ & 1.43 & 51.86 \\
\hline & Penicillamine & 5 & 2.0 & 5 & 0.7 & 3.20 & 0.1016 & 0.77 & 13.22 \\
\hline & Minocycline & 4 & 1.6 & 4 & 0.5 & 5.27 & $0.0207^{*}$ & 1.22 & 22.73 \\
\hline & Captopril & 4 & 1.6 & 4 & 0.5 & 4.87 & $0.0325^{*}$ & 1.08 & 21.77 \\
\hline
\end{tabular}

\footnotetext{
${ }^{*} p$-value $<0.05$. OR: odds raito.
} 
Table 3. Multivariate Logistic Regression Analysis (Patient Background Factor vs. Therapeutic Category)

\begin{tabular}{|c|c|c|c|c|c|c|c|c|c|}
\hline & \multirow{2}{*}{ Item } & \multicolumn{2}{|c|}{ Leucopenia } & \multicolumn{2}{|c|}{ Control } & \multirow{2}{*}{$\begin{array}{l}\text { OR } \\
1.39\end{array}$} & \multirow{2}{*}{$\begin{array}{l}p \text {-value } \\
0.0718\end{array}$} & \multicolumn{2}{|c|}{$95 \%$ C.I. } \\
\hline & & & & & & & & & \\
\hline \multirow{6}{*}{ Patient background } & Female & $\begin{array}{r}\text { Number } \\
164\end{array}$ & $\begin{array}{c}\% \\
66.1\end{array}$ & $\begin{array}{r}\text { Number } \\
359\end{array}$ & $\begin{array}{c}\% \\
48.3\end{array}$ & & & 0.97 & 2.00 \\
\hline & Elderly & 51 & 20.6 & 207 & 27.9 & 0.72 & 0.1199 & 0.47 & 1.08 \\
\hline & Autoimmune disease & 32 & 12.9 & 51 & 6.9 & 1.15 & 0.7430 & 0.48 & 2.53 \\
\hline & Renal damage & 30 & 12.1 & 47 & 6.3 & 2.71 & $0.0020^{*}$ & 1.42 & 5.03 \\
\hline & Renal damage (past) & 11 & 4.4 & 11 & 1.5 & 2.12 & 0.1644 & 0.73 & 6.15 \\
\hline & Drug rash (past) & 5 & 2.0 & 25 & 3.4 & 0.62 & 0.3702 & 0.19 & 1.63 \\
\hline \multirow{7}{*}{$\begin{array}{c}\text { Causative drugs } \\
\text { (therapeutic category) }\end{array}$} & Thyroid and Parathyroid hormone & 54 & 21.8 & 9 & 1.2 & 33.84 & $0.0001 *$ & 16.64 & 76.56 \\
\hline & Anti-peptic ulcer drug & 20 & 8.1 & 19 & 2.6 & 5.81 & $0.0001^{*}$ & 2.91 & 11.63 \\
\hline & Anti-rheumatoid drug & 19 & 7.7 & 26 & 3.5 & 3.94 & $0.0071^{*}$ & 1.47 & 10.97 \\
\hline & $\beta$-lactam drug & 19 & 7.7 & 36 & 4.8 & 3.24 & $0.0002 *$ & 1.73 & 5.91 \\
\hline & Other genitourinary drug & 17 & 6.9 & 3 & 0.4 & 29.92 & $0.0001^{*}$ & 9.60 & 131.59 \\
\hline & Sulfa drug & 15 & 6.0 & 5 & 0.7 & 19.14 & $0.0001^{*}$ & 6.89 & 62.31 \\
\hline & Psychoneurotic drug & 8 & 3.2 & 72 & 9.7 & 0.62 & 0.2361 & 0.27 & 1.29 \\
\hline
\end{tabular}

$* p$-value $<0.05$. OR: odds raito.

Table 4. Multivariate Logistic Regression Analysis (Symptoms)

\begin{tabular}{|c|c|c|c|c|c|c|c|c|c|}
\hline & \multirow{2}{*}{ Item } & \multirow{2}{*}{\multicolumn{2}{|c|}{ Leucopenia }} & \multicolumn{2}{|c|}{ Control } & \multirow{2}{*}{$\begin{array}{l}\text { OR } \\
6.85\end{array}$} & \multirow{2}{*}{$\begin{array}{c}p \text {-value } \\
0.0001^{*}\end{array}$} & \multicolumn{2}{|c|}{$95 \%$ C.I. } \\
\hline & & & & & & & & & \\
\hline & Fevers and Chills & $\begin{array}{r}\text { Number } \\
156\end{array}$ & \begin{tabular}{|c|}
$\%$ \\
62.9
\end{tabular} & $\begin{array}{r}\text { Number } \\
137\end{array}$ & $\begin{array}{c}\% \\
18.4\end{array}$ & & & 4.78 & 9.91 \\
\hline & Anemia & 73 & 29.4 & 23 & 3.1 & 14.19 & $0.0001 *$ & 8.23 & 25.22 \\
\hline Subjective symptoms & Pharyngitis, laryngitis, tonsillitis, $\cdots$ & 67 & 27.0 & 57 & 7.7 & 2.06 & $0.0028^{*}$ & 1.28 & 3.32 \\
\hline & Mouth abnormality & 21 & 8.5 & 27 & 3.6 & 0.86 & 0.7006 & 0.40 & 1.81 \\
\hline & Bleeding tendency & 12 & 4.8 & 11 & 1.5 & 1.26 & 0.7202 & 0.34 & 4.40 \\
\hline & Fevers and Chills & 143 & 57.7 & 90 & 12.1 & 8.08 & $0.0001^{*}$ & 5.67 & 11.57 \\
\hline & Pharyngitis, laryngitis, tonsillitis, $\cdots$ & 66 & 26.6 & 44 & 5.9 & 2.45 & $0.0003^{*}$ & 1.51 & 3.99 \\
\hline $\begin{array}{l}\text { Symptoms at initial } \\
\text { medical exam }\end{array}$ & Bleeding tendency & 10 & 4.0 & 6 & 0.8 & 3.94 & $0.0287^{*}$ & 1.15 & 13.76 \\
\hline & Mouth abnormality & 9 & 3.6 & 12 & 1.6 & 1.44 & 0.5037 & 0.49 & 4.10 \\
\hline & Anemia & 5 & 2.0 & (dummy) 1 & 0.1 & 28.30 & $0.0029^{*}$ & 4.18 & 555.34 \\
\hline
\end{tabular}

${ }^{*} p$-value $<0.05$. OR: odds raito.

-13.76）, 「貧血」（オッズ比 $28.30,95 \%$ C.I. $4.18-$ 555.34) であった.

6. リスク因子確率と自覚症状確率の算出とカッ トオフ值回帰式から算出したリスク因子確率, 自覚症状確率の分布を Table 5, 6 にそれぞれ示す. リスク因子確率では $\mathrm{X}=0.25$ において尤度比が 1 以上となり，かつ， ROC 曲線において感度 100 \%, 特異度 $100 \%$ から最も近い距離であったため, ここをカットオフ值とした。また自覚症状確率では $\mathrm{X}=0.4$ で尤度比が 1 以上となり, かつ, ROC 曲線 において感度 $100 \%$, 特異度 $100 \%$ から最も近い距 離であったため, ここをカットオフ值とした。な お，各区分に該当症例がない場合には尤度比の算出
は不能であったため*と表示した.

\section{7. 回帰式の妥当性評価リスク因子確率と自} 覚症状確率による推定結果を Table 7 に示す.

リスク因子確率推定において，陽性となったケー 又群の症例は 248 症例中 140 症例，陰性となったコ ントロール群の症例は 743 症例中 628 症例であっ た。感度は $56.5 \%$, 特異度は $84.5 \%$, 陽性尤度比 は 3.65 であった，特異度は $80 \%$ 以上であった。感 度は $80 \%$ に満たなかった。陽性尤度比は 1 以上で あった。自覚症状確率推定において，陽性となった ケース群の症例は 248 症例中 184 症例, 陰性となつ たコントロール群の症例は 743 症例中 585 症例であ つた。感度は $74.2 \%$, 特異度は $78.7 \%$, 陽性尤度 
Table 5. Distribution of Predictive Probability According to Risk Factor

\begin{tabular}{|c|c|c|c|c|c|c|}
\hline \multirow{2}{*}{$\begin{array}{l}\text { Probability } \\
\text { distribution } \\
\text { (\%) }\end{array}$} & \multicolumn{2}{|c|}{ Leucopenia } & \multicolumn{2}{|c|}{ Control } & \multirow{2}{*}{$\begin{array}{l}\text { Likelihood } \\
\text { ratio }\end{array}$} & \multirow{2}{*}{$\begin{array}{l}\text { Cut } \\
\text { off }\end{array}$} \\
\hline & Number & $\%$ & Number & $\%$ & & \\
\hline 0 & 0 & 0.00 & 0 & 0.00 & $*$ & \\
\hline$<5$ & 0 & 0.00 & 0 & 0.00 & $*$ & \\
\hline $5 \leqq X<10$ & 0 & 0.00 & 0 & 0.00 & $*$ & \\
\hline $10 \leqq X<15$ & 50 & 20.16 & 332 & 44.68 & 0.45 & \\
\hline $15 \leqq X<20$ & 58 & 23.39 & 296 & 39.84 & 0.59 & \\
\hline $20 \leqq X<25$ & 0 & 0.00 & 0 & 0.00 & $*$ & \\
\hline $25 \leqq X<30$ & 10 & 4.03 & 27 & 3.63 & 1.11 & $\bigcirc$ \\
\hline $30 \leqq X<35$ & 9 & 3.63 & 33 & 4.44 & 0.82 & \\
\hline $35 \leqq X<40$ & 27 & 10.89 & 33 & 4.44 & 2.45 & \\
\hline $40 \leqq X<45$ & 2 & 0.81 & 0 & 0.00 & $*$ & \\
\hline $45 \leqq X<50$ & 0 & 0.00 & 1 & 0.13 & 0.00 & \\
\hline $50 \leqq X<55$ & 3 & 1.21 & 5 & 0.67 & 1.80 & \\
\hline $55 \leqq X<60$ & 0 & 0.00 & 0 & 0.00 & $*$ & \\
\hline $60 \leqq x<65$ & 5 & 2.02 & 3 & 0.40 & 4.99 & \\
\hline $65 \leqq X<70$ & 0 & 0.00 & 0 & 0.00 & $*$ & \\
\hline $70 \leqq X<75$ & 3 & 1.21 & 1 & 0.13 & 8.99 & \\
\hline $75 \leqq X<80$ & 16 & 6.45 & 4 & 0.54 & 11.98 & \\
\hline $80 \leqq X<85$ & 20 & 8.06 & 4 & 0.54 & 14.98 & \\
\hline $85 \leqq X<90$ & 8 & 3.23 & 1 & 0.13 & 23.97 & \\
\hline $90 \leqq X<95$ & 35 & 14.11 & 2 & 0.27 & 52.43 & \\
\hline $95 \leqq X<100$ & 2 & 0.81 & 1 & 0.13 & 5.99 & \\
\hline
\end{tabular}

* acalculia.
Table 6. Distribution of Predictive Probability According to Subjective Symptom

\begin{tabular}{|c|c|c|c|c|c|c|}
\hline \multirow{2}{*}{$\begin{array}{c}\text { Probability } \\
\text { distribution } \\
\text { (\%) }\end{array}$} & \multicolumn{2}{|c|}{ Leucopenia } & \multicolumn{2}{|c|}{ Control } & \multirow{2}{*}{$\begin{array}{c}\text { Likelihood } \\
\text { ratio }\end{array}$} & \multirow{2}{*}{$\begin{array}{l}\text { Cut } \\
\text { off }\end{array}$} \\
\hline & Number & $\%$ & Number & $\%$ & & \\
\hline 0 & 0 & 0.00 & 0 & 0.00 & $*$ & \\
\hline$<5$ & 0 & 0.00 & 0 & 0.00 & $*$ & \\
\hline $5 \leqq X<10$ & 59 & 23.79 & 556 & 74.83 & 0.32 & \\
\hline $10 \leqq X<15$ & 0 & 0.00 & 0 & 0.00 & $*$ & \\
\hline $15 \leqq X<20$ & 5 & 2.02 & 29 & 3.90 & 0.52 & \\
\hline $20 \leqq X<25$ & 0 & 0.00 & 0 & 0.00 & * & \\
\hline $25 \leqq X<30$ & 0 & 0.00 & 0 & 0.00 & $*$ & \\
\hline $30 \leqq X<35$ & 0 & 0.00 & 0 & 0.00 & * & \\
\hline $35 \leqq X<40$ & 0 & 0.00 & 0 & 0.00 & $*$ & \\
\hline $40 \leqq X<45$ & 73 & 29.44 & 107 & 14.40 & 2.04 & 0 \\
\hline $45 \leqq X<50$ & 0 & 0.00 & 0 & 0.00 & $*$ & \\
\hline $50 \leqq X<55$ & 0 & 0.00 & 0 & 0.00 & * & \\
\hline $55 \leqq X<60$ & 64 & 25.81 & 49 & 6.59 & 3.91 & \\
\hline $60 \leqq X<65$ & 0 & 0.00 & 0 & 0.00 & $*$ & \\
\hline $65 \leqq X<70$ & 0 & 0.00 & 0 & 0.00 & $*$ & \\
\hline $70 \leqq X<75$ & 2 & 0.81 & 0 & 0.00 & * & \\
\hline $75 \leqq X<80$ & 0 & 0.00 & 0 & 0.00 & $*$ & \\
\hline $80 \leqq X<85$ & 0 & 0.00 & 0 & 0.00 & $*$ & \\
\hline $85 \leqq X<90$ & 0 & 0.00 & 0 & 0.00 & $*$ & \\
\hline $90 \leqq X<95$ & 23 & 9.27 & 2 & 0.27 & 34.45 & \\
\hline $95 \leqq X<100$ & 22 & 8.87 & 0 & 0.00 & $*$ & \\
\hline
\end{tabular}

* acalculia.

Table 7. Validity of Predictive Probability

\begin{tabular}{c|c|c|c|c|c}
\hline \hline \multirow{2}{*}{ Risk factor } & \multicolumn{3}{|c|}{ Estimation } & \multicolumn{2}{c}{ Validity } \\
\cline { 2 - 6 } & Leucopenia & Control & Total & Sensitivity & $56.5 \%$ \\
\hline Positive & 140 & 115 & 255 & Specificity & $84.5 \%$ \\
\hline Negative & 108 & 628 & 736 & Likelihood Ratio & 3.65 \\
\hline Total & 248 & 743 & 991 & & \\
\hline \multirow{2}{*}{$\begin{array}{c}\text { Subjective } \\
\text { symptoms }\end{array}$} & \multicolumn{2}{|c|}{ Estimation } & & \multicolumn{2}{c}{ Validity } \\
\cline { 2 - 7 } Positive & 184 & 158 & 342 & Specificity & $78.7 \%$ \\
\hline Negative & 64 & 585 & 649 & Likelihood Ratio & 3.49 \\
\hline Total & 248 & 743 & 991 & & \\
\hline
\end{tabular}


比は 3.49 であった。感度，特異度ともに $80 \%$ に満 たなかった。陽性尤度比は 1 以上であった。

Lazarou ら ${ }^{12)}$ の報告から得られた副作用有病率 15.1\%を基に白血球減少症の推定有病率を算出した.

CARPIS 全有効症例 44563 症例中，なんらかの白 血球減少症を起こしている症例の総数は 1029 症例 であった．推定有病率は約 $0.35 \% （ 1029 /[44563 /$ 0.151]）であった。リスク因子確率推定における推 定陽性反応的中度は $1.3 \%$ ，推定必要患者数は約 79 人（1/0.013）であった。自覚症状確率推定におけ る推定陽性反応的中度は $1.2 \%$ ，推定必要患者数は 約 83 人 (1/0.012) であった.

さらに, リスク因子確率と自覚症状確率による推 定を照合した結果を Table 8 に示す。ケース群にお いてリスク因子確率，自覚症状確率ともに陽性と推 定された症例（陽性/陽性）は 114 症例，陽性/陰性 は 26 症例，陰性/陽性は 70 症例，陰性/陰性は 38 症例であった。コントロール群においてリスク因子 確率，自覚症状確率ともに陽性と推定された症例

Table 8. Verification of Two Measures of Predictive Probability

\begin{tabular}{c|c|c|c|c|c}
\hline \hline & \multicolumn{5}{|c}{ Risk factor/Subjective symptoms } \\
\cline { 2 - 6 } & $+/+$ & $+/-$ & $-/+$ & $-/-$ & Total \\
\hline Leucopenia & 114 & 26 & 70 & 38 & 248 \\
\hline Control & 28 & 87 & 130 & 498 & 743 \\
\hline
\end{tabular}

+ : Positive, - : Negative.

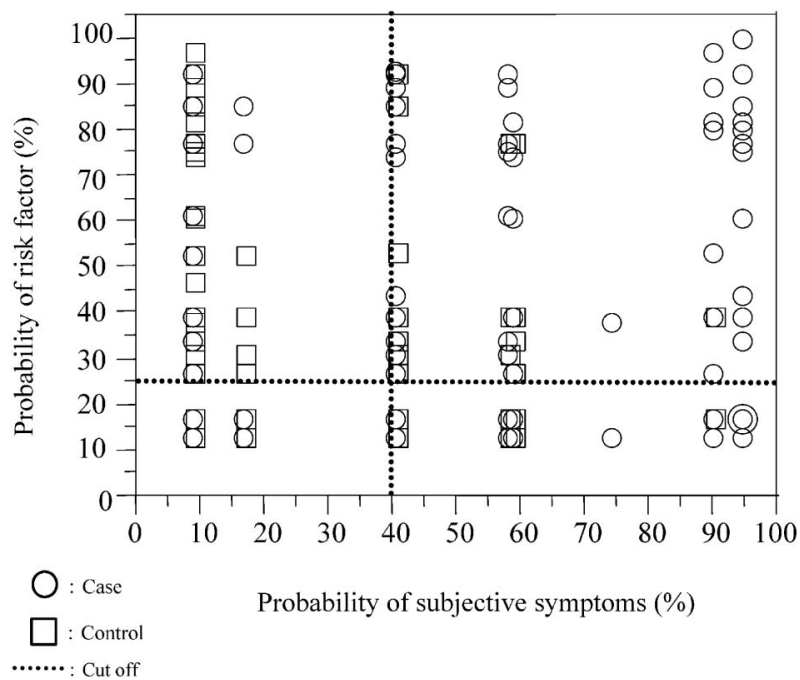

Fig. 2. 2D Analytical Plot
（陽性/陽性）は 28 症例，陽性/陰性は 87 症例，陰 性/陽性は 130 症例，陰性/陰性は 498 症例であっ た。またこれらの結果を二次元展開したものを Fig. 2 に示した。

\section{考察}

薬物性白血球減少症の危険因子と自覚症状を明ら かにするために，白血球減少症が発現した症例を ケース群，それ以外の副作用が発現した症例をコン トロール群としてケースコントロール研究を行つた.

患者背景と原因薬（一般名）で多変量ロジスティ ック回帰分析を行った結果，有意なリスク増加が認 められた項目は「女性」,「自己免疫疾患」,「腎障害」, 「チアマゾール」,「塩酸リトドリン」,「プロピルチ オウラシル」,「塩酸チクロピジン」,「アロプリノー ル」，「塩酸ミノサイクリン」，「カプトプリル」であ つた.

今回の研究結果では，患者背景である「女性」が コントロール群の $48.3 \%$ に対しケース群の $66.1 \%$ （オッズ比 $1.43,95 \%$ C.I. 1.00-2.06）を占めてお り，男性よりも多く，女性が薬物性白血球減少症を 起こし易いことが分かった。 van Staa ら13)もイギ リスで行ったケースコントロール研究で白血球減少 症は女性に多かった（ケース群の $68.4 \%$ ）と報告 している，さらに，厚労省マニュアルでも「女性」 は無顆粒球症の危険因子に挙げられている.4) しか し，原因薬を詳細に検討すると，「甲状腺・副甲状 腺ホルモン」が多く認められた。「甲状腺・副甲状 腺ホルモン」の適応となる甲状腺機能障害のうち， バセドウ病は男女比が $1 ： 4.5$ と女性に多い疾患で あることが知られている. ${ }^{14)}$ 今回の結果はこの影響 を受けた可能性もあると考えられる．また，Huerta ら $^{15)}$ は抗生物質処方患者を対象として行った薬 物性白血球減少症のケースコントロール研究におい て，その発現に男女差はみられなかったと報告して いる，よって，患者背景である「女性」が白血球減 少症の独立した危険因子であるかどうかについては さらなる検討が必要であると考えられる。

次に患者背景にある疾患で「自己免疫疾患」の背 景がある患者は白血球減少症のリスクが 2.23（95 \%C.I. 1.19-4.02) 倍になるという結果が得られた. 別所ら 16) も「自己免疫疾患」が白血球減少症の危険 因子であると報告している。近年，白血球減少症の 
中にも自己抗体を産生する薬物性自己免疫性好中球 減少症の存在が知られており, 好中球特異抗原に対 してマクロファージ食食, 単球やリンパ球による抗 体依存性細胞障害機序などが考えられている. ${ }^{17)}$ 今 回の結果からも「自己免疫疾患」は薬物性白血球減 少症の独立した危険因子になり得ると考えられ， 「自己免疫疾患」が背景にある患者が白血球減少症 を起こし易い薬物を使用する場合に注意が必要であ ると考えられる。

「腎障害」はオッズ比 1.95 （95\%C.I. 0.99-3.70） で有意なリスク増加を示した。吉田ら ${ }^{18)}$ は「腎障害」 がある患者は白血球減少症のリスクが高くなると述 ベている．また，厚労省マニュアルにおいても「腎 機能低下」は無顆粒球症の危険因子に挙げられてい る。腎機能が低下すると薬物血中濃度の上昇や排泄 遅延から，通常の服用量でも血中濃度が中毒域とな り副作用が出易くなる。したがって，「腎障害」の ある患者に対する投薬については，投与設計はもち ろんのこと, 副作用発現のモニタリングという観点 においても十分な注意が必要である.

一方，「高齢」は有意なリスク増加を示さなかっ た．高齢者では加齢による腎機能の低下から，前述 のように成人投与量でも副作用の発現する場合が多 くなる. ${ }^{19)}$ また，高齢者では加齢とともに自己抗体 発現にネガティブフィードバックをかけているサプ レッサー T 細胞の働きが弱くなるため, 自己抗体 が出現し易いことが知られている。 ${ }^{20)}$ 薬物性白血球 減少症の機序として前述の自己免疫性好中球減少症 があることから，「高齢」は薬物性白血球減少症の 危険因子に十分なり得ると考えられる。また，厚労 省マニュアルにおいても「高齢」は無顆粒球症の危 険因子に挙げられている。 しかし，今回の研究で有 意な結果は得られなかった。これは今回の研究にお けるコントロール群が白血球減少症以外の副作用を 起こした症例であり，白血球減少症以外の副作用も また高齢者では発現し易くなるため，「高齢」との 関係が過小評価された可能性がある.

原因薬としては，抗甲状腺薬である「チアマゾー ル」の重篤な副作用として白血球減少症が知られて いるが，今回の研究でも最も高いオッズ比を示した (オッズ比 54.68, 95 \% C.I. 21.45-185.14)。 チアマ ゾールによる白血球減少症の機序としては，特定の HLA クラス抗原（DRB1*08032）との関連が認め
られ，薬物により顆粒球増殖に関与する成長因子が 修飾されることで構造変化が生じていることが推測 されている. ${ }^{21)}$ Hamerschlak ら ${ }^{22)}$ が中南米で 150 人 （ケース群 30 人）を対象として行つた無顆粒球症に ついてのケースコントロール研究では，チアマゾー

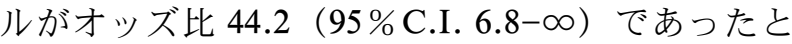
報告しており，今回の結果と近い值であった。 ま た，「プロピルチオウラシル」もオッズ比 15.97 （95\% C.I. 4.73-72.69）と有意なリスク増加を示し, 薬効分類名による解析でも「甲状腺・副甲状腺ホル モン」がオッズ比 33.84 （95\% C.I. 16.64-76.56）の リスク増加を示す結果が得られた。 van Staa ら13) が行ったケースコントロール研究では抗甲状腺薬が オッズ比 34.7 （95\% C.I. 12.0-99.7） であったと報 告しており，非常に近いオッズ比を示し，今回の結 果はそれを支持するものと考えられる.

「塩酸リトドリン」はオッズ比 26.88（95\% C.I. 8.69-117.71）と 2 番目に高いリスク増加を示した. 山田ら ${ }^{23)}$ により行われた 2008 年塩酸リトドリン注 射薬の副作用実態調査において，切迫早産患者の中 に白血球減少症の発現を確認している．正常な妊娠 時における白血球の数は妊娠初期に増加し，中期は 横ばい，後期にはやや減少する推移を示すと報告さ れている. ${ }^{24)}$ また, 渡辺 ${ }^{25)}$ は白血球増加が切迫早産 の指標になると報告している。白血球数増加は胎児 を包む脱落膜の炎症を反映しており，炎症によって 大量の白血球が消費されることが考えられる，一方， in vitro では高濃度の塩酸リトドリンが顆粒球・マ クロファージ前駆細胞の増殖を抑制することが分か つており, ${ }^{26)}$ 白血球が大量に必要な状況で塩酸リト ドリンが投与された場合には，白血球の増殖が間に 合わず，減少する可能性が考えられる。ささらに，妊 娠中の母体の免疫系は異物である胎児を許容するた めに細胞傷害活性を持つ Th1 細胞（helper T cell 1) やNK 細胞（natural killer cell）の活性が著明に抑

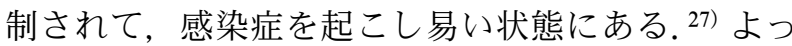
て，塩酸リトドリンの対象が妊婦であることを考慮 すると十分な注意が必要である，薬効分類名の「そ の他の泌尿生殖器官・肛門用薬」でみられる有意な リスク増加（オッズ比 29.92 , 95\% C.I. 9.60-131.59） は「塩酸リトドリン」の反映した結果であると考え られる。

「塩酸チクロピジン」はオッズ比 $21.62 （ 95 \%$ C.I. 
5.12-146.63）と高いリスク増加を示した。 Ibanez ら 28 が 763 人（ケース群 177 人）を対象としたケー スコントロール研究でも，塩酸チクロピジンが無顆 粒球症に最も強く関連した薬物であったと報告して いる（オッズ比 103.23, $95 \%$ C.I. 12.73-837.44）. また，塩酸チクロピジンについては厚生労働省より 過去に 2 度の緊急安全性情報が発出されており，そ の中で副作用の予防，早期発見のために投与開始 2 カ月間は 2 週毎の血液検查を行うように注意喚起が なされている。 なお，今回のケース症例においても 8 症例中 6 症例が投与後 2 力月以内に発現してお り，投与開始 2 力月間で副作用を発現する割合は高 く，注意が必要である，今回はそのリスクの高さを 定量化して示すことができた.

「アロプリノール」はオッズ比 $7.05 （ 95 \%$ C.I. 1.43-51.86）の有意なリスク増加を示した。 アロプ リノールの副作用に関しては，その代謝物である才 キシプリノールの蓄積が副作用機序の 1 つと考えら れている. ${ }^{29)}$ アロプリノールに比べてオキシプリ ノールの半減期は 14-26 時間と長く, 腎機能低下時 には用量依存的に血清オキシプリノール濃度が上昇 することが報告されている. ${ }^{30)}$ 今回の研究では, ケース群の 6 症例すべてで腎障害の合併症が確認さ れた。 また，そのうちの 3 症例では減量措置がされ ていたにもかかわらず白血球減少症を発現してい た．添付文書においても腎機能障害のある患者では 投与量の減量や投与間隔の延長を考慮するよう注意 をしているが，リスク因子のある患者においては投 与設計だけでなく，その後の副作用モニタリングが さらに重要であると考える。

一方，「メトトレキサート」は有意なリスク増加 が認められなかった。今回の解析では抗がん薬によ る白血球減少症を除外したため，「メトトレキサー ト」は「抗リウマチ薬」として低用量で使用された ものである.メトトレキサートによる血液障害の機 序は，細胞分裂の盛んな骨髄などの健常細胞に対し て毒性を引き起こすことによる，久我は, ${ }^{31)}$ メトト レキサートによる血液障害は $0.1 \mu \mathrm{M}$ 以上の濃度へ の暴露が 72 時間以上続いた場合に発現すると述べ ている。 つまり，低用量の使用でも排泄遅延が原因 で薬物への暴露時間が長くなると副作用の危険が高 くなる．さらに久我は排泄遅延のきっかけとして， かぜや下痢，発熱，脱水などのシックデイを挙げ,
体調不良時のメトトレキサートの休薬を提案してい る. 今回の結果からは抗リウマチ薬として使用され る「メトトレキサート」が白血球減少症の原因とな ることは少ないが，副作用の発現には原因薬のほか にも様々な危険因子が存在するため, 使用後のモ二 タリングや患者指導を十分に行うことが必要だと考 える.

自覚症状における多変量ロジスティック回帰分析 では,「発熱・悪寒」,「貧血」,「咽頭異常」におい て有意な正の関連が認められた。

「発熱・悪寒」はケース群において最も多く報告 された自覚症状であり $(62.9 \%)$ ，オッズ比 6.85 (95\%C.I. 4.78-9.91) であった。初期症状において もオッズ比は 8.08 (95\%C.I. 5.67-11.57） と高かっ た．厚労省マニュアルでは「突然の高熱」,「さむけ」 が白血球減少症の自覚症状として挙げられており, 早期発見するために自覚し易い症状として重要であ ると考えられる。

「咽頭異常」について, 咽頭粘膜には咽頭扁桃, 口蓋扁桃, 舌扁桃などのリンパ性組織があり, 細 菌・ウイルスなどの侵入を防ぐ働きを担ってい る. ${ }^{32)}$ 白血球減少時にはこの機能が低下して上気道 感染などが起こり易くなり，咽頭異常が起こる.

「咽頭異常」は自覚症状でオッズ比 2.06 （95\%C.I. 1.28-3.32），初期症状でオッズ比 2.45（95\% C.I. 1.51-3.99）であり，医薬品の使用後に咽頭異常が 起こった場合には白血球減少症を予測し，対応する ことが重要だと考える，厚労省マニュアルにおいて も「のどの痛み」が自覚症状として挙げられており， 今回はその程度を数值として示すことができた.

「貧血」と初期症状において有意差が認められた 「出血傾向」については，汎血球減少よる影響が大 きいと考える．自覚症状で「貧血」が認められたケー 又群 73 症例を確認したところ, 汎血球減少症は 50 症例であった。 また，初期症状で「出血傾向」が認 められたケース群 10 症例のうち汎血球減少症は 7 症例であった。したがって「貧血」と「出血」は白 血球減少の症状としてではなく, 汎血球減少の症状 として重要であると考える。

リスク因子確率からの薬物性白血球減少症の推定 において，特異度は基準を満たしたが，感度は満た さなかった。これは，陰性と推定されてしまった症 例の原因薬が今回の解析対象に含まれていなかった 
ためと考えられる.ケース群であるにもかかわらず 陰性と判定されてしまった 108 症例中，解析に含ま れていた薬剤が原因薬となっていたのは 10 症例だ けであった．今回解析対象となった薬物はケース群 の原因薬の $51 \%$ であり，残りの $49 \%$ は症例数が少 なかったため今回の解析には含まれていない。また, 1 症例しか報告がなかった薬物はケース群の原因薬 の $25 \%$ を占めていた. したがって，原因薬をさら に追究するためには，患者背景と原因薬を分けて解 析する必要性も考慮すべきと考える。陽性尤度比の 影響は 2 以上 5 未満が有用性小， 5 以上 10 未満で 有用性中，10 以上で有用性大とされている．陽性 尤度比は 3.65 なので妥当性があり，わずかな有用 性があると評価した。

自覚症状確率からの白血球減少症の推定において は感度，特異度ともに基準を満たさなかった。これ は，白血球減少により発現する自覚症状全般が種々 の副作用で発現する自覚症状であり, 白血球減少症 に特異的な自覚症状が少ないことが原因と考えられ る. また，白血球減少症は無症状で血液検査によっ て発見されることも多いと言われており,4,17) 今回 のケース群においても 62 症例が無症状であった.

陽性尤度比は 3.49 で妥当性があり，わずかな有効 性があると評価した。しかし, 白血球減少症の自覚 症状は特異性が低く, 多くの疾患, 副作用で自覚さ れる症状であるため, 症状だけで白血球減少症と推 定することは難しいと考える.

薬剤性無顆粒球症についてはいくつかの症例対照 研究が報告されており，その発症率は 0.8-7/100 万 人 $/ 1$ 年 $(0.00008-0.0007 \% / 1$ 年) であったとされ ている. ${ }^{1,13,22,28)}$ 本研究の推定有病率は $0.35 \%$ とこ れらの報告より大きかった。これは今回の推定有病 率がなんらかの薬剤を服用している患者における薬 剂性白血球減少症全体を含めた有病率を推定したも のであり，無顆粒球症のみならず検查值異常として の白血球減少も多く含まれているためと考えた.

推定有病率から求めた本式の推定必要患者数はリ スク因子確率推定, 自覚症状確率推定においてそれ ぞれ約 79 人，約 83 人であった。これは 1 人の白血 球減少症の可能性のある患者を見い出すためにはそ れぞれ約 79 人，約 83 人の患者に対して本判定方法 を用いて検討を行わなければならないということで あり，白血球減少症をリスク因子確率推定，自覚症
状確率推定それぞれのみで推測することは難しいと 考えられた。

リスク因子確率と自覚症状確率の両方を用いて行 った推定において，ケース群でリスク因子確率，自 覚症状確率ともに陽性と推定された 114 症例は，こ の回帰式を利用することでリスク因子と自覚症状か ら薬物性白血球減少症の早期発見につなげることが できるのではないかと考える，血液検査ができない 環境で患者背景や自覚症状から副作用を早期発見 し，重篤化を防ぐことが可能であると示唆された。

一方, リスク因子確率, 自覚症状確率ともに陰性 と推定されたケース群の 38 症例は薬物性白血球減 少症であるにもかかわらず今回の回帰式による推定 では見逃されてしまった，今後，回帰式の精度を上 げるためにさらなる検討が必要であると考える.

コントロール群でリスク因子確率, 自覚症状確率 ともに陽性と予測された 28 症例のうち, すべてが 白血球減少症に関連したなんらかの自覚症状を発現 していた。このうち「発熱・悪寒」が 22 症例で発 現していた。「発熱・悪寒」だけで白血球減少症を 予測することは難しいが，原因薬などの他のリスク 因子が存在するときには予測できる可能性は高くな る。薬物を服用した後に「発熱・悪寒」が発症した 場合には白血球減少症の可能性を考え，血液検査を 行う必要があると考える.

今日，副作用被害に遭つた症例報告から得られた 貴重なデー夕をより臨床で有用に活用するために も，薬剤師の対応行動に結びつく検討は意義深いも のと考える. 二次元展開図において，リスク因子確 率と自覚症状確率がともにカットオフ值を超えるも のは，薬物性白血球減少症が強く疑われるため，処 方医に情報提供を行い，注意して早期発見や重篤化 の防止に努めることが重要であると考える．自覚症 状確率は低いがリスク因子確率でカットオフ值を超 えるものについては，症状が発現していなくてもリ スク因子が高いことから，今後の症状の発現に注意 して，検査や観察をすることで早期発見につなげる ことができると考える。この場合患者への情報提供 も行い患者自身への注意を促して, 症状の早期発見 に努めることも重要である。リスク因子確率が低 く, 自覚症状確率がカットオフ值を超えるものにつ いては，原因薬を確認した上で，その症状発現がも ともとの疾患によるものや他の副作用による可能性 
があるため，処方医に情報提供を行い，注意・観察 をしながら他の手がかりとなる情報を収集する必要 があると考える。

薬物性白血球減少症は，原因薬が様々であり，リ スク因子も乏しく，特異的な自覚症状も少ないこと から，血液検査をしなければ発見し難い副作用であ る。しかし，薬物治療しているほとんどの患者は外 来患者であり，頻繁に検査を受けることは難しい. そこで，患者背景や症状の訴えから今回の回帰式を 利用することで血液検査のできない薬局においても 副作用の早期発見・重篤化防止に努めることが可能 であると考える。

本研究は，日本国内で報告された副作用症例を副 作用のコホートとして研究材料にしたものである. 本来，副作用の実態を把握するためには大規模な前 向き研究が必要である。しかし，白血球減少症のよ うな発現頻度の低い副作用に対して前向き研究を行 うことは難しい，厚労省マニュアルの危険因子も疫 学調査に基づいたデータではなく, 副作用への寄与 の程度についても示されてはいない。その中で，今 回，薬物性白血球減少症の危険因子や自覚症状を定 量化して示すことができた本研究手法は大変意義が あると考える。また，今回作成した回帰式に関して は，今後さらなる検討を行うことで精度を増してい くことが可能であると考える.

医薬品を使用するにあたり，有効性だけでなく， 副作用に着目することは薬剤師の重要な役割であ る。しかし，稀な副作用を目にする機会は非常に少 なく，それに対応する情報もあまりない，本研究は 白血球減少症という稀ではあるが重篤な副作用に関 して，原因薬の特徵や早期発見の手がかりとなる症 状を疫学調査に基づいて示すことができた。このよ うな副作用の危険因子に関する医薬品情報の研究 は，医療現場での薬剤師業務に大きく貢献すると考 える，不幸にも医薬品による副作用に遭遇した過去 の貴重な患者情報を今後の副作用未然防止へつなげ ることは薬剤師の社会的責務である.

\section{REFERENCES}

1) Kaufman D. W., Kelly J. P., Jurgelon J. M., Anderson T., Issaragrisil S., Wiholm B.-E., Young N. S., Leaverton P., Levy M., Shapiro S., Eur. J. Haematol., 57 (S60) , 23-30 (1996).
2) Kishimoto Y., Medicine and Drug Journal, 34, 2611-2616 (1998) .

3) Ministry of Health, Labour and Welfare: 〈http: // www.mhlw.go.jp / shingi / 2005 / 07 / s0719-4.html $\rangle$, cited 15 November, 2010.

4) Japanese Society of Clinical Hematology, "Jyutokufukusayoushikkanbetsutaiou

Manual," Vol. 1, Japan Pharmaceutical Information Center, Tokyo, 2007, pp. 259-276.

5) Ohtsu F., Yano R., Inagaki K., Drug Inf. J., 40, 115-122 (2006).

6) Inagaki K., Ohtsu F., Tada M., Ninomiya E., Japan Journal of Medical Informatics, 10, 255 -265 (1990).

7) JDream II, Japan Science and Technology Agency: 〈http://pr.jst.go.jp/jdream2/index. html $\rangle$, cited 15 November, 2010.

8) ICHUSHI, Japana Centra Revuo Medicina: 〈http://www.jamas.or.jp/service/ichu/about. html $\rangle$, cited 15 November, 2010.

9) iyakuSearch, Japan Pharmaceutical Information Center: 〈http://database.japic.or.jp/nw/ index $\rangle$, cited 15 November, 2010.

10) Ohtsu F., Yano R., Inagaki K., Yakugaku Zasshi, 120, 120-131 (2000).

11) CIOMS (Council for International Organizations of Medical Sciences), Int. J. Clin. Pharmacol. Ther. Toxicol., 29, 75-81 (1991).

12) Lazarou J., Pomeranz B. H., Corey P. N., JAMA, 279, 1200-1205 (1998) .

13) van Staa T. P., Boulton F., Cooper C., Hagenbeek A., Inskip H., Leufkens H. G., Am. J. Hematol., 72, 248-254 (2003).

14) Sasaki N., Journal of Clinical and Experimental Medicine, 195, 410-412 (2000).

15) Huerta C., Rodriguez L. A. G., Pharmacotherapy, 22, 630-636 (2002).

16) Bessho M., The Journal of Therapy, 89, 32313234 (2007).

17) Ito T., Miura R., Japanese Journal of Clinical Medicine (Suppl.), 190-193 (2000).

18) Yoshida T., Yamada H., Rheumatology, 32, 129-135 (2004).

19) Miyazaki C., Chozai to Joho, 14, 794-798 (2008)

20) Kishimoto S., Hujii T., Japanese Journal of Clinical Medicine, 42, 882-889 (1984).

21) Yokogoshi H., Kosaka M., Medicine and Drug Journal, 34, 840-846 (1998) . 
22) Hamerschlak N., Maluf E., Biasi Cavalcanti A., Avezum Júnior A., Eluf-Neto J., Passeto Falcão R., Lorand-Metze I. G. H., Goldenberg D., Leite Santana C., de Oliveira Werneck Rondrigues D., Nascimento da Motta Passos L., Oliveira de Miranda Coelho E., Tostes Pintão M. C., Moraes de Souza H., Borbolla J. R., Pasquini R., Eur. J. Clin. Pharmacol., 64, 921-929 (2008).

23) Yamada S., Mizuno K., Ikeda Y., Mori K., Fujiyoshi K., Miyata K., Abstracts of papers, the 16th Clinical Pharmacy Symposium, Tokyo, July 2008, No. 16, p. 189.

24) Tsukada I., Kogure M., Kodama K., Momose Y., Obstet. Gynecol. (Tokyo), 51, 765-769 (1984).

25) Watanabe H., Matsubara S., Perinatal Medicine, 34, 152-154 (2004).
26) Tsukimori K., Morokuma S., Yoshimura T., Muta K., Wake N., Br. J. Clin. Pharmacol., 65, 149-150 (2008).

27) Sakai M., Saito S., Sanfujinka Chiryo, 86, 787 -793 (2003).

28) Ibanez L., Vidal X., Ballarin E., Laporte J.R., Arch. Intern. Med., 165, 869-874 (2005) .

29) Puig J. G., Casas E. A., Ramos T. H., Michan A. A., Mateos F. A., J. Rheumatol., 16, 842844 (1989).

30) Okada H., Oita A., Ueno K., Takada M., Shibakawa M., Jpn. J. Pharm. Health Care Sci., 28, 64-570 (2002).

31) Kuga Y., Journal of Musculoskeletal System, 19, 527-537 (2006).

32) Sakai A., "Medemirukaradano Mecanism," Igaku-Shoin Co., Ltd., Tokyo, 1996, p. 32. 